\title{
Determination of the Deoxyribonucleic Acid Composition and Deoxyribonucleic Acid-Deoxyribonucleic Acid Hybridization of Fusobacterium fusiforme, Fusobacterium polymorphum, and Leptotrichia buccalis: Taxonomic Considerations
}

\author{
LAWRENCE R. PAGE' AND GEORGE N. KRYWOLAP \\ Department of Microbiology, University of Maryland Dental School, Baltimore, Maryland 21201 \\ The deoxyribonucleic acids (DNA) of Fusobacterium polymorphum ATCC \\ 10953 and $F$. fusiforme ATCC 23726 were submitted to DNA-DNA hybridization \\ procedures. A polynucleotide homology of $78 \%$ was demonstrated, indicating \\ that the recent grouping of all oral Fusobacterium strains into one species, $F$. \\ nucleatum, should be reevaluated. The polynucleotide homology between Lepto- \\ trichia buccalis ATCC 19616 and the two strains of Fusobacterium tested was \\ less than $30 \%$. The guanine plus cytosine $(\mathrm{G}+\mathrm{C})$ values of the DNA of Fusobac- \\ terium and Leptotrichia strains tested were similar and unusually low (24.5 to \\ $25.6 \mathrm{~mol} \%$ ). Since bacteria of the family Bacteroidaceae reportedly have $\mathrm{G}+\mathrm{C}$ \\ values of 41 to $42 \mathrm{~mol} \%$, the placing of the genera Fusobacterium and Leptotri- \\ chia into this family is questionable. The similar unusually low $\mathrm{G}+\mathrm{C}$ values of \\ the DNA of Fusobacterium and Leptotrichia may indicate a close phylogenetic \\ relationship for these genera.
}

Considerable confusion exists in the literature concerning oral strains of Fusobacterium. Knorr $(14,15)$ originated the generic name $F u$ sobacterium and described three species based on cellular morphology: $F$. plauti-vincentii, $F$. polymorphum, and $F$. nucleatum. However, it became evident that the cellular morphology of the fusobacteria was too inconsistent to be a reliable taxonomic criterion. Several additional classification schemes were subsequently proposed that utilized colonial morphology and serological and biochemical characteristics $(8,24-$ 26). Unfortunately, none of these characteristics was sufficient to allow subclassification of the oral fusobacteria. As a result, in 1941 Boe (1) proposed combining all oral fusobacteria into one species. More recently, a similar conclusion was reached by Werner and co-workers (27) when they also were unable to define consistent phenotypic criteria for the subclassification of these microorganisms. Thus, Moore and Holdeman (21) combined all oral fusobacteria into one species, $F$. nucleatum, the type species of Fusobacterium. In addition, the genus $F$ usobacterium was retained in the family Bacteroidaceae by Moore and Holdeman (21).

A second genus of oral bacteria, Leptotrichia, has often been confused with Fusobacterium because of morphological similarities $(8,25$, 26). Boe (1) attempted to separate these genera,

' Present address: Department of Oral Pathology, University of Kentucky College of Dentistry, Lexington, Ky. 40506 . but the confusion continued when Hoffman (9) described $L$. buccalis as $F$. fusiforme. Moore and Holdeman (21) recognized the genus Leptotrichia as a separate entity and placed it in the family Bacteroidaceae. The present study was designed to investigate the taxonomic relationship between strains of Fusobacterium and of L. buccalis by comparing the guanine plus cytosine $(\mathrm{G}+\mathrm{C})$ contents of their deoxyribonucleic acids (DNA) and by using DNA-DNA hybridization. In addition, the placement of the genera Fusobacterium and Leptotrichia into the family Bacteroidaceae was evaluated by comparing the $\mathrm{G}+\mathrm{C}$ content of their DNA to that reported for members of Bacteroides, the type genus of the family Bacteroidaceae.

(A preliminary report of this research was presented at the 75th Annual Meeting of the American Society for Microbiology, New York, N.Y., 27 April to 2 May 1975. This paper is based on a portion of a thesis submitted by $L$. R. P. to the Graduate School, University of Maryland at Baltimore City in partial fulfillment of the requirements for the Ph.D. degree, 1975.)

\section{MATERIALS AND METHODS}

Bacterial strains. The strains used in this study were $F$. fusiforme ATCC 23726, $F$, polymorphum ATCC 10953, $L$. buccalis ATCC 19616, and $L$. buccalis ATCC 23471. In Table 1 are listed the metabolic characteristics useful in distinguishing between $F u$ sobacterium and Leptotrichia.

Cultivation. Cells were grown in a modified 
TABLE 1. Metabolic characteristics useful in distinguishing between Leptotrichia and Fusobacterium

\begin{tabular}{lccl}
\hline \multicolumn{1}{c}{ Genus } & $\begin{array}{c}\mathrm{H}_{2} \mathrm{~S} \\
\text { prod- } \\
\text { uction }\end{array}$ & $\begin{array}{c}\text { Indole } \\
\text { produc- }^{a}\end{array}$ & End product \\
tion $^{b}$ & & - & Lactate \\
Leptotrichia & - & - & Butyrate \\
\hline
\end{tabular}

" Semisolid agar (BBL); 48-h growth.

${ }^{b}$ Indole nitrate medium (BBL), 24-h growth, followed by the addition of Kovacs reagent.

tryptone medium consisting of $1 \%$ tryptone (Difco), $1 \%$ yeast extract (Difco), $0.125 \% \mathrm{~K}_{2} \mathrm{HPO}_{4}, 0.125 \%$ $\mathrm{MgSO} 4 \cdot 7 \mathrm{H}_{2} \mathrm{O}$, and $0.2 \%$ glucose, at $\mathrm{pH} 7.2$ (7). Cultures were grown on a rotary shaker in GasPak anaerobic jars (BBL) at $37^{\circ} \mathrm{C}$ for $24 \mathrm{~h}$ and harvested by centrifugation at $10,000 \times g$ for $10 \mathrm{~min}$; the bacterial pellets were stored at $-20^{\circ} \mathrm{C}$ until needed for DNA extraction.

Isotope labeling of DNA. DNA labeling was accomplished by adding $10 \mu \mathrm{Ci}$ of $\left[5{ }^{3} \mathrm{H}\right]$ adenine (5 to $15 \mathrm{Ci} / \mathrm{mmol}$; New England Nuclear Corp., Boston, Mass. $)$ and $\left[2{ }^{3} \mathrm{H}\right]$ thymidine $(6.7 \mathrm{Ci} / \mathrm{mmol}$; New England Nuclear Corp., Boston, Mass.) per ml to the above-mentioned medium. Cells were grown, harvested, and stored as described above.

Lysis of cells. A modification of the Marmur technique (20) was used for lysis of bacterial cells and DNA purification. Frozen bacterial pellets were suspended in a small volume of saline-EDTA $(5 \mathrm{ml} / \mathrm{g}$ of frozen pellet weight; $0.15 \mathrm{M} \mathrm{NaCl}, 0.1 \mathrm{M}$ ethylenediaminetetraacetate [EDTA], pH 8). Lysozyme $(3 \times$ crystalline; Nutritional Biochemicals Corp., Cleveland, Ohio) was added to a final concentration of 1.5 $\mathrm{mg} / \mathrm{ml}$ of cell suspension. The suspension was then incubated in a $37^{\circ} \mathrm{C}$ water bath for 4 to $5 \mathrm{~h}$. At this time, an equal volume of a Pronase-SLS solution (2\% sodium lauryl sulfate [SLS] [Fisher Scientific Co., Pittsubrgh, $\mathrm{Pa}$. $]$ containing $0.5 \mathrm{mg}$ of nucleasefree Pronase [B grade; Calbiochem, LaJolla, Calif.] per $\mathrm{ml}$ ) was added, and the suspension was incubated for 16 to $20 \mathrm{~h}$ in a $37^{\circ} \mathrm{C}$ water bath, after which lysis was complete.

Extraction and purification of DNA. The lysate was centrifuged at $8,000 \times g$, and the supernatant was recovered for DNA extraction. The addition of sodium perchlorate to a final concentration of $1 \mathrm{M}$ was followed by a chloroform-isoamyl alcohol protein extraction. Nucleic acids were spooled onto glass rods after the addition of 2 volumes of cold ethyl alcohol. The nucleic acids were suspended in 2 to $5 \mathrm{ml}$ of $1 \times \mathrm{SSC}\left(0.15 \mathrm{M} \mathrm{NaCl}, 0.015 \mathrm{M} \mathrm{Na}_{i s}\right.$ citrate, $\mathrm{pH} 7.0)$, and heat-treated ribonuclease $\left(80^{\circ} \mathrm{C}\right.$ for $10 \mathrm{~min}, 5 \times$ crystalline; Nutritional Biochemicals Corp., Cleveland, Ohio) was added to a final concentration of $100 \mu \mathrm{g} / \mathrm{ml}$. The solution was incubated in a $37^{\circ} \mathrm{C}$ water bath for $40 \mathrm{~min}$. Nuclease-free Pronase, self-digested for $1 \mathrm{~h}$ at $37^{\circ} \mathrm{C}$, was added to a final concentration of $100 \mu \mathrm{g} / \mathrm{ml}$, and incubation was continued for another $45 \mathrm{~min}$. The solution was placed into $5-\mathrm{ml}$ cellulose nitrate centrifuge tubes, and cesium chloride (code 62; Rare Earth Division, Ameri- can Potash and Chemical Co., W. Chicago, Ill.) was added to a final concentration of $1.251 \mathrm{~g} / \mathrm{ml}$. The gradients were centrifuged at $25^{\circ} \mathrm{C}$ for $48 \mathrm{~h}$ at 69,100 $\times g$. Visible bands of DNA, detected when tubes were placed over high-intensity light, were recovered through the sides of the tubes. Labeled DNA was dialyzed with $2 \times \mathrm{SSC}\left(0.3 \mathrm{M} \mathrm{NaCl}, 0.03 \mathrm{M} \mathrm{Na}_{3}\right.$ citrate, $\mathrm{pH}$ 7.0). Unlabeled DNA was dialyzed with $6 \times \mathrm{SSC}\left(0.1 \mathrm{M} \mathrm{NaCl}, 0.09 \mathrm{M} \mathrm{Na}_{3}\right.$ citrate, $\mathrm{pH} \mathrm{7.0)}$. Quantitative measurements of DNA were by the method of Burton (4). The absence of protein contamination was monitored by the procedures of Lowry et al. (17).

Determination of DNA base composition. Thermal denaturation of DNA samples was carried out by the method of Mandel and Marmur (18). Buoyant-density determinations were carried out, using an analytical ultracentrifuge (19), on calf thymus DNA and Bacterionema matruchotii WHB9A DNA to determine the accuracy of our thermal denaturation data. The $\mathrm{G}+\mathrm{C}$ difference between the two methods was less than $2 \mathrm{~mol} \%$.

DNA-DNA hybridization. The hybridization procedure used was a slight modification of that described by Legault-Demare et al. (16) and later by DeLey and Tijtgat (5). Unlabeled DNA was denatured to single-stranded form by placing $50 \mathrm{ml}$ of a $6 \times \mathrm{SSC}$ solution containing $30 \mu \mathrm{g}$ of DNA per ml into a flask and heating it in a $100^{\circ} \mathrm{C}$ water bath for $20 \mathrm{~min}$. The flask was transferred to an ice bath, and $100 \mathrm{ml}$ of cold $6 \times$ SSC was added quickly. Denaturation was monitored by comparing the absorbance at $260 \mathrm{~nm}$ of the undiluted DNA solution before and after heating. DNA was bound to nitrocellulose membrane filters ( $25 \mathrm{~mm}, 0.45-\mu \mathrm{m}$ pore size, type B6 ; Schleicher and Schuell, Inc., Germany) by passing it through $5 \mathrm{ml}$ of the denatured DNA solution. Binding efficiency was determined by comparing the absorbance at $260 \mathrm{~nm}$ of the DNA solution before and after the passages through the filters. The filters were washed with $6 \times$ SSC and dried.

Labeled DNA, dialyzed in $2 \times \mathrm{SSC}$, was fragmented by sonic treatment and denatured by the method described above.

At least $5 \mu \mathrm{g}$ of labeled DNA can be added to a filter with $30 \mu \mathrm{g}$ of unlabeled DNA (1:6 ratio) without saturating the filter (5). However, in this study a minimum 1:35 ratio was used to insure a wide margin below the saturation level. To vials containing the dried filters was added $0.8 \mathrm{ml}$ of $2 \times \mathrm{SSC}$ $\mathrm{Me}_{2} \mathrm{SO}_{4}\left(1.403 \mathrm{~g}\right.$ of $\mathrm{NaCl}, 0.706 \mathrm{~g}$ of $\mathrm{Na}_{3}$ citrate, $50 \mathrm{ml}$ of distilled water, and $30 \mathrm{ml}$ of $\mathrm{N}_{2}$-bubbled dimethyl sulfoxide $\left.\left[\mathrm{Me}_{2} \mathrm{SO}_{4}\right]\right)$, after which $0.2 \mathrm{ml}$ of labeled DNA $(1 \mu \mathrm{g})$ was added and the vials were incubated in a $43^{\circ} \mathrm{C}$ water bath for $18 \mathrm{~h}(5,16)$. Filters were then washed once in $30 \% \mathrm{Me}_{2} \mathrm{SO}_{4}-70 \% 2 \times \mathrm{SSC}$, once in $15 \% \mathrm{Me}_{2} \mathrm{SO}_{4}-85 \% 2 \times \mathrm{SSC}$, and three times in $2 \times$ SSC. After the filters were dried, scintillation fluid consisting of $4 \mathrm{~g}$ of Omnifluor (New England Nuclear Corp., Boston, Mass.) per liter of toluene was added, followed by scintillation counting. Percent hybridization was determined by dividing the counts per minute for the heterologous hybridization samples by the counts per minute for the homologous hybridization samples. 


\section{RESULTS AND DISCUSSION}

The $\mathrm{G}+\mathrm{C}$ contents of the two strains of Fusobacterium and two strains of Leptotrichia tested, as well as those of other members of the family Bacteroidaceae, are shown in Table 2. The fusobacteria tested in this study, as well as those tested by Johnson (13), have similiar, very low $\mathrm{G}+\mathrm{C}$ values ( 25 to $27 \mathrm{~mol} \%$ ). The Leptotrichia strains also have similarly low $\mathrm{G}+\mathrm{C}$ values. In contrast, the Bacteroides species have $\mathrm{G}+\mathrm{C}$ values between 41 and $42 \mathrm{~mol} \%$, considerably higher than those for Fusobacterium and Leptotrichia strains.

The average binding efficiency of unlabeled DNA to nitrocellulose membrane filters was $92 \%$. Only filters with at least $35 \mu \mathrm{g}$ of DNA bound were used in these experiments.

The average efficiency of renaturation for these hybridization experiments was $47.3 \%$.

Table 3 lists the DNA-DNA homology of the Fusobacterium and Leptotrichia strains tested. The DNA of each strain was labeled and tested against the unlabeled DNA of the other strain.

In the present study, $F$. fusiforme ATCC 23726 and F. polymorphum ATCC 10953 were found to have a $78 \%$ polynucleotide homology. DNA homology studies reported in the literature usually have revealed that strains of the same species have over $80 \%$ homology $(2,3,6)$. On the other hand, bacteria of different species occasionally have been shown to have high homology levels ranging from $75 \%$ to as much as $94 \%(10,12,22,23)$. The homology range of 75 to $85 \%$ seems to be the borderline for species differentiation. Because of the lack of definite guidelines for species differentiation, the combining of all oral fusobacteria into one species cannot be shown to be untenable on the basis of this study. However, at best, the DNA homology of the strains of $F$. polymorphum and $F$.

TABLE 2. $G+C$ content of DNA of selected members of the family Bacteroidaceae

\begin{tabular}{lc}
\hline \multicolumn{1}{c}{ Taxon } & $\begin{array}{c}\mathrm{G}+\mathrm{C} \text { content } \\
(\mathrm{mol} \%)\end{array}$ \\
\hline Bacteroides fragilis & $42^{\prime \prime}$ \\
B. melaninogenicus & $41.5^{b}$ \\
B. nigrescens & $41.5^{b}$ \\
Fusobacterium varium & $27^{\prime \prime}$ \\
F. mortiforum & $27^{\prime \prime}$ \\
F. polymorphum ATCC 10953 & $25.6^{\circ}$ \\
F. fusiforme ATCC 23726 & $25.3^{\circ}$ \\
L. buccalis ATCC 19616 & $24.5^{\circ}$ \\
L. buccalis ATCC 23471 & $24.8^{\circ}$ \\
\hline
\end{tabular}

"See reference 13.

$b$ See reference 11 .

" Data derived from the present investigation.
TABLE 3. Average percent homology of DNA of selected members of the family Bacteroidaceae

\begin{tabular}{ccc}
\hline Strain & $\begin{array}{c}\text { Leptotrichia } \\
\text { buccalis } \\
\text { ATCC 19616 }\end{array}$ & $\begin{array}{c}\text { Fusobacte- } \\
\text { rium fusi- } \\
\text { forme ATCC } \\
23726\end{array}$ \\
$\begin{array}{c}\text { Fusobacterium polymorphum } \\
\text { ATCC 10953 }\end{array}$ & 29.7 & 78.1 \\
$\begin{array}{c}\text { Fusobacterium fusiforme } \\
\text { ATCC 23726 }\end{array}$ & 28.6 & 100 \\
\hline
\end{tabular}

fusiforme tested was at the lower end of the range acceptable for different strains of the same species. These results suggest that the combining of oral fusobacteria into one species should be reevaluated.

The polynucleotide homology between the two strains of $L$. buccalis and the two strains of Fusobacterium tested is less than $30 \%$, too low to indicate more than the possibility of closely related genera.

The DNAs of the Leptotrichia and Fusobacterium strains studied have similar, very low $\mathrm{G}+\mathrm{C}$ values $(24.5$ to $25.6 \mathrm{~mol} \%$ ). There is approximately a $16 \mathrm{~mol} \%$ difference in the $\mathrm{G}+\mathrm{C}$ content of the DNA of strains of these two genera and those of other members of the family Bacteroidaceae reported in the literature. It is unlikely that such large differences are due to variation in laboratory techniques, especially since one of the studies cited (13) reported $\mathrm{G}+\mathrm{C}$ values for the Fusobacterium strains tested within $2 \%$ of the values reported here. It is concluded that Fusobacterium and Leptotrichia are not closely related to the Bacteroidaceae species reported and that these two genera probably do not belong in the family Bacteroidaceae. Furthermore, the similar, unusually low $\mathrm{G}+\mathrm{C}$ values for Fusobacterium and Leptotrichia may indicate a close phylogenetic relationship for these genera.

\section{ACKNOWLEDGMENTS}

This work was supported by Public Health Service grant 5 TO1 DE00088-13 from the National Institute of Dental Research and by the Drew Endowment Fund of the University of Maryland.

\section{REPRINT REQUESTS}

Address reprint requests to: Dr. George N. Krywolap, Department of Microbiology, Baltimore College of Dental Surgery, Dental School, University of Maryland, Baltimore, Md. 21201.

\section{LITERATURE CITED}

1. Boe, J. 1941. Fusobacterium. Studies on its bacteriology, serology and pathogenicity. Nor. Vidensk.Akad. Oslo. I. Mat.-Naturv. Klasse, 9:1-191.

2. Brenner, D. J., G. R. Fanning, and A. G. Steigerwalt. 1974. Polynucleotide sequence relatedness in $E d$ wardsiella tarda. Int. J. Syst. Bacteriol. 24:186-190.

3. Brenner, D. J., G. R. Fanning, and A. G. Steigerwalt. 
1974. Deoxyribonucleic acid relatedness among erwiniae and other Enterobacteriaceae: the gall, wilt, and dry-necrosis organisms (genus Erwinia Winslow et al., sensu stricto). Int. J. Syst. Bacteriol. 24:197204.

4. Burton, K. 1968. Determination of DNA concentration with diphenylamine, p. 163-166. In L. Grossman and $\mathrm{K}$. Moldave (ed.), Methods in enzymology, vol. 12B. Academic Press Inc., New York.

5. DeLey, J., and R. Tijtgat. 1970. Evaluation of membrane filter methods for DNA-DNA hybridization. Antonie van Leeuwenhoek., J. Microbiol. Serol. 36:461-474.

6. Dellaglio, F., M. Vescovo, and L. Premi. 1974. "Free" diaminopimelic acid and deoxyribonucleic acid homology of Lactobacillus helveticus. Int. J. Syst. Bacteriol. 24:235-237.

7. Gilmour, M. N., and A. E. Poole. 1970. Growth stimulation of the mixed microbial flora of human dental plaques by haemin. Arch. Oral Biol. 15:1343-1353.

8. Hine, M. K., and G. P. Berry. 1937. Morphological and cultural studies on the genus Fusiformis. J. Bacteriol. 34:517-534.

9. Hoffman, H. 1957. F usobacterium Knorr, p. 436-440. In R. S. Breed, E. G. D. Murray, and N. R. Smith (ed.), Bergey's manual of determinative bacteriology, 7th ed. The Williams and Wilkins Co., Baltimore.

10. Hoyer, B. H., and N. B. McCullough. 1968. Polynucleotide homologies of Brucella deoxyribonucleic acids. J. Bacteriol. 95:444-448.

11. Jackson, F. L., Y. E. Goodman, F. R. Bel, P. C. Wong, and R. L. S. Whitehours. 1971. Taxonomic status of facultative and strictly anaerobic "corroding bacilli" that have been classified as Bacteroides corrodens. J. Med. Microbiol. 4:171-184.

12. Jain, K., K. Radsak, and W. Mannheim. 1974. Differentiation of the Oxytocum group from Klebsiella by deoxyribonucleic acid-deoxyribonucleic acid hybridization. Int. J. Syst. Bacteriol. 24:402-407.

13. Johnson, J. L. 1973. Use of nucleic-acid homologies in the taxonomy of anaerobic bacteria. Int. J. Syst. Bacteriol. 23:308-315.

14. Knorr, M. 1922. Uber die fusospirilläre Symbiose, die Gattung Fusobacterium (K. B. Lehmann) und Spirillum sputigenum. (Zugleich ein Beitrag zur Bakteriologie der Mundhöhle) I. Mitteilung: die Epidemiologie der fusospirillaren Symbiose, besonders der PlautVincentschen Angina. Zentralbl. Bakteriol. Parasitenkd. Infektionskr. Hyg. Abt. 1 Orig. 89:536-545

15. Knorr, M. 1923. Uber die fusospirillare Symbiose, die
Gattung Fusobacterium (K. B. Lehmann) und Spirillum sputigenum. (Zugleich ein Beitrag zur Bakteriologie der Mundhölhle) II. Mitteilung: die Gattung $F u$ sobacterium. Zentralbl. Bakteriol. Parasitenkd. Infektionskr. Hyg. Abt. 1 Orig. 89:4-22.

16. Legault-Demare, J., B. Desseaux, T. Heyman, S. Seror, and G. P. Ress. 1967. Studies on hybrid molecules of nucleic acids. 1. DNA-DNA hybrids on nitrocellulose filters. Biochem. Biophys. Res. Commun. 28:550-557.

17. Lowry, O. H., N. J. Rosebrough, A. L. Farr, and R. J. Randall. 1951. Protein measurement with the Folin phenol reagent. J. Biol. Chem. 193:265-275.

18. Mandel, M., and J. Marmur. 1968. Use of ultraviolet absorbance-temperature profile for determining the guanine plus cytosine content of DNA, p. 195-206. In L. Grossman and K. Moldave (ed.), Methods in enzymology, vol. 12B. Academic Press Inc., New York.

19. Mandel, M., C. L. Schildkraut, and J. Marmur. 1968. Use of $\mathrm{CsCl}$ density gradient analysis for determining the guanine plus cytosine content of DNA, p. 184-195. In L. Grossman and K. Moldave (ed.), Methods in enzymology, vol. 12B. Academic Press Inc., New York.

20. Marmur, J. 1961. A procedure for the isolation of deoxyribonucleic acid from microorganisms. J. Mol. Biol. 3:208-218.

21. Moore, W. E. C., and L. V. Holdeman. 1974. Fusobacterium Knorr 1922, p. 404-416. In R. E. Buchanan and N. E. Gibbons (ed.), Bergey's manual of determinative bacteriology, 8th ed. The Williams and Wilkins Co., Baltimore.

22. Ritter, D. B., and R. K. Gerloff. 1966. Deoxyribonucleic acid hybridization among some species of the genus Pasteurella. J. Bacteriol. 92:1838-1839.

23. Roop, D. R., J. O. Mundt, and W. S. Riggsby. 1974 Deoxyribonucleic acid hybridization studies among some strains of group D and group $\mathrm{N}$ streptococci. Int. J. Syst. Bacteriol. 24:330-337.

24. Slanetz, L. W., and L. F. Rettger. 1933. A systematic study of the fusiform bacteria. J. Bacteriol. 26:599620.

25. Spaulding, E. H., and L. F. Rettger. 1937. The Fusobacterium genus. I. Biochemical and serological classification., J. Bacteriol. 34:535-548.

26. Varney, P. 1927. The serological classification of fusiform bacilli. J. Bacteriol. 13:275-314

27. Werner, H., F. Neuhaus, and H. Hussels. 1971. A biochemical study of fusiform anaerobes. Med. Microbiol. Immunol. 157:10-16. 